\title{
Relevance of Kautilya's tax system in Modern Economy of Nepal
}

\author{
Dil Nath Dangal
}

\begin{abstract}
Taxes, usually regarded as an unpleasant subject, are compulsory levies for the general purposes of the government. The objective of this article is to make comparative study between Kautilya tax system and modern tax system of Nepal. For methodology that helps meet the objective of this study, historical and analytical research design has been used. Based on this objective and methodology, this study finds many concepts of Nepali-modern tax system are profoundly influenced by the tax system of Kautilya.
\end{abstract}

Keywords : Kautilya, value added tax, customs duty, excise duties, income tax, indirect tax, direct tax, land registration, vehicle tax

\section{Introduction}

Taxation and economic development are two closely interrelated concepts. Taxation plays an important role in country's economic development. Nepal, being in the process of economic development, needs higher government expenditure to meet the purposed development programs. To open the way for smooth development of economy, government has to finance large amount of money in preparing basic infrastructures such as road, airport, schools, colleges, hospitals, pure drinking water, and education. To build the infrastructures, government of Nepal lacks sufficient amount of resources. Taxation, therefore, is an effective measure to collect sufficient amount of money for government expenditure. Taxation is not only an instrument of obtaining higher revenue, but also a medium to eliminate undesirable effects in the economy — and to introduce desirable effects (As cited in Dangal, 2018).

Very significant concepts on taxation by Kautilya are systematically presented in his famous text Arthasastra He talks in detail about the prosperity of King ( rulers) and the country. Kautilya identified power of the ruler depends on these seven factors: the qualities of the king, the qualities of his ministers, his provinces, his city, his treasury, his army, and his allies. The aim of the Arthasastra was to instruct the king on how to improve the qualities of these factors and undermine those of his enemies. Whatever the nature of accounts of his life, Kautilya was a historical figure and he was responsible for the compilation of a work on polity, which has exerted a profound influence on the development of political

* Dr. Dangal is Lecturer in Economics in T.U. 
ideas in traditional India. The Arthasastra is a manual of instruction on the administration of a state and ways to meet its challenges. Kautilya was a consummate political realist and often gives the impression of being amoral. The Arthasastra deals with the many facets of governmental administration and pays special attention to war, preparation for it, and its triumphant execution. The Arthasastra deals with a system of politics or principles based on practical rather than moral or ideological considerations. Kautilya's Arthasastra contains 15 books. The first five deal with tantra (internal administration of the state). The next eight deal with avapa (its relations with neighbouring states) and the last two are miscellaneous in character. The eighth adhikarna is concerned with vyasanas (the calamities, shortcomings or weaknesses affected by different forms of Nature). The ninth adhikarna deals with preparation for war and describe the kinds of troops that should be mobilised for an expedition. The tenth adhikarna deals with fighting. Kautilya lived in a period of constant warfare and realised the importance of studying war as an important aspect of statecraft. The Arthasastra forms the foundation of intrinsic Indian strategic thought. Its basic advantage is that it is a written text as opposed to oral tradition in India. This monograph covers its military aspects. In Kautilyan terms, a nation needs to skillfully employ its strengths against the weakness of enemy. The asymmetric approach to conquest was understood and approved, and it fits into contemporary pragmatic Indian culture. In this context, the Indian policy of nonalignment was directly Kautilyan - a means of enhancing security by a low-risk strategy of playing one superpower off against another until India could gain sufficient strength to protect its own security. The ideas propounded by Kautilya are still useful in the political scene of India. He was successful in developing the science of politics, and his principles are seen being used by political scientists and defense analysts today (Singh, 2013).

\section{Objectives}

The objective of this study is to make a comparative study between Kautilya's tax system and modern tax system of Nepal.

\section{Research methodology}

This research study is based on historical and analytical research design to make a comparative study between Kautilya tax systems and modern tax system of Nepal. Historical facts related to Kautilya and notification related to modern tax system are studied to complete the research.

\section{Literature review}

Kautilya favoured the increase in tax base, not the tax rate. His discussion on taxation gave an idea of three principles: Taxation power is limited, taxation should not be heavy, and tax increase should be moderate. He recommends a system of tax collection in such a 
way as to build up the permanent revenue-yielding capacity of the economy. He advocated indirect taxes like excise duties and customs duties, and direct taxes as income tax on individuals, wealth tax, and profession tax. According to him, tax receipts can be divided into three parts: income earned through taxes on goods produced within a country, income earned through taxes on goods produced in the capital, and income earned through taxes on imports and exports. He advocated the ability to pay approach those rich persons should pay higher tax according to their paying capacity (Tanwar, 2014).

Kautilya described, in detail, the trade and commerce carried on with foreign countries and the active interest of the Mauryan Empire to promote such trade. Goods imported from China, Ceylon, and other countries, and levy known as a vartanam was collected on all foreign commodities imported in the country. There was another levy, called Dvarodaya, that was paid by the concerned businessman for the import of foreign goods. In addition, ferry fees of all kinds were levied to augment the tax collection. Collection of income tax was well organized and it constituted a major part of the revenue of the state (Rana, 2008).

Kautilya implicitly suggests a linear income tax. He emphasizes fairness and stability of tax structure, fiscal federalism, avoidance of heavy taxation, ensuring of tax compliance, and subsidies to encourage capital formation (Sihag, 2009).

A tax is a compulsory levy and those who are taxed have to pay it without getting corresponding benefit of services or goods from the government. Taxpayer cannot receive any quid pro quo for the payment of tax (Dahal,1983). The taxpayer does not receive equivalent benefit from the government. The tax is paid to the government for running it. In case of tax, the amount is spent for common interest of the people. The tax is collected from rich people and spent basically for the interest of common and poor people in the society (Kandel, 2004).

\section{Analysis}

\section{Kautilya tax system}

Kautilya gave so much importance to public finance, and the taxation system in the Arthasastra is not far to seek. According to him, the power of the government depended upon the strength of its treasury. Kautilya said that the power of the government come from the treasury, and the earth, whose ornament is the treasury, is acquired by means of the treasury and army. However, the author regarded revenue and taxes as the earning of the sovereign for the services rendered by him to the people and to afford them protection and to maintain law and order. Kautilya emphasized that the King was only a trustee of the land and his duty was to protect it and to make it more and more productive so that land revenue 
could be collected as a principal source of income for the State. Kautilya's tax system was not a compulsory contribution by the subject to the State, but the relationship was based on Dharma and it was the King's sacred duty to protect its citizens in view of the tax collected and if the King failed in his duty, the subject had a right to stop paying taxes, and even to demand refund of the taxes paid (Rana, 2008).

Kautilya's Arthasastra deals with the system of taxation in a real elaborated and planned manner. This wellknown treatise on state crafts written sometime in 300 B.C.- when the Mauryan Empire was as its glorious upwards move-is truly amazing, for its deep study of the civilization of that time and for the suggestions given which should guide a king in running the state in a most efficient and fruitful manner. A major portion of Arthasastra was devoted by Kautilya to financial matters including financial administration. According to famous statesman, the Mauryan system, so far as it applied to agriculture, was a sort of state landlordism and the collection of land revenue formed an important source of revenue to the state. The State not only collected a part of the agricultural produce which was normally one sixth but also levied water rates, octroi duties, tolls, and customs duties. Taxes were also collected on forest produce as well as from mining of metals and so forth. Salt tax was an important source of revenue, and it was collected at the place of its extraction (Rana, 2008).

The tax of Kautilya taxation system was paid on the basis of the quality of land utility productivity, and facilities from 16.66 per cent to 25 per cent of total production for agricultural labour, landless farmer, had provided 25 per cent of total production by government. But the tax was compulsory for contract land user according to agreement. But land tax was discount for new farmer when he does not get double benefit. It is clear that tax should be changed in profit (Gyawali, 2011).

Kautilya tax system was different. Businessman paid tax according to business transaction. They had to pay 50 per cent tax from gold, silver, diamond, horse, elephant businessman. 30 per cent from oil, fiber, metal businessman, 20 per cent for glass and 20 per cent for big boat makers and so forth. Retail skilled manpower, prostitute, house manager should pay 10 per cent tax from their additional income. It was compulsory to pay 5 per cent tax for bamboo, stone, soil pot, and eatable shopkeeper. But there was system of tax 1 per cent for dancer, singer and counter. If skilled man, productive manpower stayed leisure, they had to pay tax and they would not get chance to be leisure. This statement was found in Kautilya's economics (Gyawali, 2011). 


\section{Modern tax system}

\section{Direct and indirect taxes}

Taxes can most conveniently be divided into two categories: direct and indirect. Direct taxes are levied immediately on the persons who are to bear the burden, and indirect taxes are those that are not so levied (Hicks, 1959). In the traditional language, if impact and incidence fall upon the same person, then the tax is said to be direct; if not and the burden is shifted and the real income of someone else is affected (i.e., impact and incidence are upon different people), then the tax is indirect(Walker, 1953).

\section{(a) Direct tax}

Direct tax creates the direct burden on individual. In other words, in indirect tax individuals are liable to pay tax from their personal income. This tax is really paid by the same person upon whom it is legally imposed.

Dalton considered the direct tax as one that is really paid by the person on whom it is legally imposed. Under the study, the major components of direct tax are income tax, land revenue and registration, and property tax. Income tax, the major component of direct tax, also carries various subcomponents to sum up the income tax, such as income tax from public enterprises, income tax from semipublic enterprises and income tax from private cooperate bodies, tax on remuneration, individual income tax, and tax on interest. Similarly, property tax includes urban house and land tax, and vehicle tax.

\section{(b) Indirect tax}

Indirect tax is imposed on one person but paid partly or wholly by another. So, the impact and incidence of tax lie upon different persons. It is transferable, and people pay tax when they consume or receive goods and services. It is transferable, and people donot feel burden of lump sum. There is mass participation because every person pays tax for receipt of goods and services. Indirect tax can be charged at higher rate for harmful goods, such as tobacco and alcohol to discourage them. Customs duties, excise duties, and Value-Added Tax are the examples of indirect tax. In the context of Nepali revenue structure, the contribution of the indirect tax to GDP, total revenue and tax revenue has always been significant.

Indirect taxes, a major revenue source in developing countries, tend to be regressive with respect to income for two reasons. First, total consumption expenditure of households are a declining fraction of income for successively higher income classes. Second, expenditure on some heavily taxed items, such as tobacco and beer, are often a declining fraction of total consumption as income rises. However, a careful selection of objects of indirect taxation 
and tax rates can result in a distribution of indirect taxes that is broadly proportional or progressive with respect to income or total consumption (Goode, 1984).

\section{Comparison modern tax system of Nepal with Kautilya tax system}

Time is dynamic and responsible for the change in the world. The situation may change according to time it could not remain constant. The government of a country needs sufficient revenues to maintain peace and security, to implement development plans, and to operate administration sources of government revenues taxes are collected from public enterprises and other grants. Kautilya was economist before $300 \mathrm{BC}$ most of the activities of that time are changing for example, population size, social cultural structure, technological changes. The Kautilya's tax system was different from modern taxation system. However, the foundation of modern taxation system is Kautiliya taxation system. These are presented below:

(1) a. The taxes mentioned in Kautilya Arthashastra is consistent with the VAT because the former states that the 50 per cent tax should be imposed on total profits of business from the sales of animals and gold.

b. According to Kautilya Arthastra, 20 per cent of fees were charged on the sales price of the goods imported from abroad and from distant places within the country. Besides, Kautilya Arthasastra also talked about customs duties, export duties, and visa (Prabesh Sulka). These descriptions almost similar to the modern tax systems.

c. Kautilya Arthasastra has explained that one-sixth, one-eight, and one-twentieth of the agricultural crops should be taken as a tax by the government, a tax system that is similar to excise duties in the modern tax system.

d. Kautilya Arthasastra has described that workers should provide their one day's labour to the government as a tax. This description indicates the income tax in the modern tax system.

e. There was a land-tax system in Kautilya's period. At that period, farmers had to pay 16.16 per cent to 25 per cent tax to their government. Likewise, this tax system is still found prevailing now as a land tax. Another similarity is found on imposing different levels of taxes on the basis of different classes of land: (i) highly productive, irrigable land, (ii) medium-level land based on rainfall and (iii) lowproductivity land. Here, Kautilya's potrahit bhumi refers to Ricardo's marginal land. 
f. In time of Kautilya, the government used to impose road tax on the users in order to clean and repair the roads. The path tax has now turned into vehicle tax in the modern taxation system.

(2) Like the modern tax, Kautilya's Arthasastra has also talked about tax and nontax. In Kautilya's Arthasastra, Prathamnath Banarjee has divided the government revenue into tax revenue and nontax revenue. Here, the tax revenues contain pinda kar, shenabhakta fee, consumption tax (balibhag), tax and path tax. Similarly, the nontax revenue includes the revenue from royal agriculture, animal husbandry, and transaction; grant; loan; the revenue from private business sector; principal and interest; and sources. This tax system is also found in the modern tax system.

\section{Similarity on canons of taxation in Kautilya and modern economics}

This article has found the following similarities between Kautilya and modern economics on the canons of taxation:canon of convenience, canon of certainty, canon of economy, canon of diversity, and canon of elasticity.The other similarities between these two tax systemshave listed below:

The canon of modern tax system say that the main source of government revenue in tax is based on Kautilya tax system. According to Kautilya, the tax should be collected by king to be strong(Sharma,1967).

Modern taxation says that the poor people should be kept out of tax system. If they have capacity to pay, they should pay it. If they have no capacity to pay, the government should encourage them by up lifting their income source. In Kautilya tax system tax should be taken from people by king by saying ripe fruits of garden. They should be leaved saying unripe fruit of garden.

Modern taxation system talks about disadvantages of indirect tax. Those who earn more income may trick tax, and Kautilya says that the king should be punished if he tricks tax and earn illegal property. Both views have same foundation.

Modern taxation system is based on progressive tax system. Those who earn more income should pay more tax: It is based on Kautilya's tax system. He said that king should be taken $1 / 3,1 / 4$ part tax according to the fertility of productive land and provide tax discount for low productive area like road, industry, and Mine.

Modern taxation system says that the area of tax should be wide. It is also based on Kautilya tax system. He said that tax should be collected from all business man, former, and prostitute. 
The modern tax system also provides the provision about tax discount. It is also based on Kautilya tax system.

Kautilya said that tax rate should be different for businessman 50 per cent from animals' business man 1/10 from goat, sheep, buffalo, cow, camel and 1/50 for gold, silver, diamond 1/40 part for cloth, copper, herbs, wine, 1/30 for shied oil, Iron. Modern tax system also differs from food, cloth, electricity, vehicles part medicine raw materials, entertainment sectors. So, these different tax systems appeared same with Kautilya.

\section{Conclusion}

The foundation of taxation was laid during the time of Kautilya. Most of the concepts of modern taxation finds seminal ideas in has Arthasastra, of course in rudimentary form. Hence Kautilya's tax system forms the foundation of modern tax systems: VAT, customs duties, excise duties, income tax, land tax, and vehicle taxes; Adam Smith's canon of taxations; and the two sources of revenues are tax and nontax sources. Since Kautilya times, a number of changes have taken place in social and economic life so economic activities got their forms changed: Population size, social cultural structure, technological changes. The Kautilya's tax system as such is not applicable to our time but its concepts form the foundational concepts for modern taxation system and so these concepts are important. In a nutshell, the very concept of modern taxation system owes heavily to Kautilya taxation system.

\section{References}

Agrawal, S.N. (1967).Indian public finance. Bombay, India: Vara and Co.

Amatya, S. K., Pokharel, B. B., \& Dahal, R. K. (2004). Taxation in Nepal. Kathmandu, Nepal: M.K. Publisher and Distributors.

Buchanan, J. M. (1965). The public finance. Dunfermline, United Kingdom: Richard D. Irwin.

Byanju, K.(2009). A study on house and land tax in Bhaktapur Municipality (Unpublished master's thesis). Tribhuvan University, Nepal Commerce Campus, Kathmandu, Nepal.

Dahal, M. K. (1983). Taxation in Nepal: A study of its structure, productivity and burden (Unpublished doctoral dissertation). University of Bombay, India.

Dangal, D. N. (2018).An analysis of Nepali modern tax system with reference to Kautilya Arthasastra (Unpublished doctoral dissertation). Nepal Sanskrit University, Dang, Nepal. 
Dhungana, B. (1980). Indirect taxation in Nepal. Kathmandu: Center for Economic Development and Administration (CEDA).

Goode, R. (1984). Government finance in developing countries. New Delhi, India: McGraw Hill.

Gyawali, B. R. (2011). Economic arrangements in Kautilya's Arthasastra and Shukra niti and utilization of government fund (Unpublished doctoral dissertation). Nepal Sanskrit University, Dang, Nepal.

Kandel, P. R. (2004). Tax laws \&tax planning in Nepal. Kathmandu, Nepal:Buddha Academy.

Luitel, T.P. (2011). Kautilya's Arthasastra [Kautilya economics]. Kathmandu, Nepal: Vidharthi.

Organization for Economic Cooperation and Development. (2012).Consumption tax trend 2012:VAT/GST and excise rates, trends and administration issues, Author. https:// dx.doi.org/10.1787/ctt-2012-en

Poudyal, K. B. (1998). Corporate tax planning in Nepal. Pokhara, Nepal: Sita Poudyal.

Rana, A. S. (2008). An analysis of tax structure and responsiveness of tax yields in Nepal (Unpublished doctoral dissertation). Tribhuvan University, Faculty of Humanities, Office of Dean, Kathmandu, Nepal.

Sharma, S. N. (1967). Kautilya ko Arthasastra [Kautilya economics] (K. R. Aryal, Trans.). Kathmandu, Nepal: Royal Nepal Academy.

Sihag, B. S. (2009). Kautilya on principles of taxation.Humanomics, 25 (1).

Singh, C. H. (2013). The Kautilya Arthasastra[The Kautilya economics] : A military perspective. New Delhi, India: KW Publishers. Retrieved from http://www. claws.in

Tanwar, R. (2014). An analytical study of the relevance of Arthshastra in modern India. Journal of Economics and Finance, 5(3), 32-35. Retrieved from http://www.iosrjournals.org

Thapa, G. B. (2001). Origin and theory of income taxation. Rajswa [Revenue], 21 (11), 24-30.

Walker, D. (1953). The direct-indirect tax problems-fifteen years of controversy. Public Finance, 10. 